10.2478/aucft-2021-0006

\title{
BIOACTIVE, ANTIOXIDANT AND ANTIDIABETIC PROPERTIES OF COOKED AND UNCOOKED IRISH POTATO (SOLANUM TUBEROSUM)
}

- Research paper -

\author{
Kayode Olayele KARIGIDI ${ }^{1 *}$, Babatunde Joseph OSO ${ }^{* *}$, Emmanuel Sina AKINTIMEHIN*, \\ Omolola Maria ODUSOLA*, Foluso Olutope ADETUYI* \\ * Chemical Sciences Department, Olusegun Agagu University of Science and Technology, \\ Okitipupa, Nigeria \\ ** Biochemistry Department, Macpherson University, Seriki Sotayo, Ogun State, Nigeria
}

\begin{abstract}
Potatoes are considered very important staple and antioxidant-rich tubers in human diet. The present study evaluated the bioactive, antioxidant, antidiabetic and inhibition of lipid peroxidation properties of cooked and uncooked Irish potatoes. The samples were subjected to total phenolic (TPC), total antioxidant capacity (TAC), total flavonoids (TFC), ascorbic acid (AsA) and 2,2-diphenyl-1-picrylhydrazyl (DPPH) radical scavenging activity analyses using spectrophotometric method. Also $\mathrm{Fe}^{2+}$-induced lipid peroxidation, $\alpha$-glucosidase and $\alpha$-amylase inhibition were assayed. The results revealed that there is no significant $(\mathrm{p}<$ $0.05)$ difference in TPC and TAC of the potatoes samples but there was a significant $(\mathrm{p}<0.05)$ enhancement in TFC and reduction in AsA of the cooked potatoes. There is also dose-dependent inhibition in DPPH and $\alpha$-glucosidase and $\alpha$-amylase enzymes. The $\mathrm{IC}_{50}$ revealed that cooked sample has significant higher $(\mathrm{p}<$ 0.05 ) inhibition in the enzymes assay. The lipid peroxidation was also reduced upon incubation with Irish potato samples but higher inhibition was exhibited by the cooked potato. In conclusion, this study has shown that Irish potato can be a good functional food in the management of diseases.
\end{abstract}

Keywords: Phenolics, Flavonoid, $\alpha$-glucosidase, $\alpha$-amylase, Lipid peroxidation.

\section{INTRODUCTION}

In recent years, regular consumption of functional foods has been encouraged due to the roles they play in human health and disease prevention. This is because; higher consumption of such foods has been correlated with a reduced incidence of chronic diseases such as hypertension, diabetes mellitus and certain classes of cancer (Heidemann et al., 2008). These preventive and curative effects are due to the many bioactive and health-promoting phytochemicals in such foods. Some of the biological activities reported for foods include antioxidant, antidiabetic, anti-inflammatory and anticancer activities (Wronkowska, et al., 2020).

Diabetes mellitus (DM) is an endocrine disease depicted by increased blood glucose level and disturbance of lipid, protein and carbohydrate metabolism (Karigidi and Olaiya, 2019). Presently,

Received: 12.01.2021

Accepted in revised form: 25.03 .2021 it is affecting about 500 million people worldwide (IDF, 2019). Excessive activities of $\alpha$-glucosidase and $\alpha$-amylase enzymes have been implicated as one of the likely causes of elevated blood sugar in DM. Due to this; these enzymes have become a clinical target in the treatment and management of DM (Shim et al., 2003). Also, many studies have confirmed enhanced lipid peroxidation in diabetes mellitus and this contributes to various organs' damage usually experienced by diabetic patients (Griesmacher et al., 1995; Alharby et al., 2019).

Irish Potato (Solanum tuberosum L.), belongs to the family of Solanaceae. It is an herbaceous, annual tuber crop that has the basic nutrients essential for proper growth and maintenance (Wailare and Madu 2019). In Nigeria, apart from using it as foods, it is also used in industrial production of starch, glucose, biscuits and drinks (Wailare and Madu 2019). Irish potato has been shown to possess less sugar and carbohydrates than

${ }^{1}$ Corresponding author. E-Mail address: karigidikayode@yahoo.com 
sweet potato (Eke-ejiofor 2015; Ikanone et al., 2014). Uncooked Irish potatoes flour is usually processed with maize flour to make traditional delicacy in Kenya (Kabiru and Imungi 1991) and also used as substitute for wheat in confectionary industries (Samsher et al., 2020).

Due to the recent awareness of uses of functional foods for prevention and management of chronic

\section{MATERIALS AND METHODS}

Fresh tubers of Irish potato (Solanum tuberosum L.) used in this study were purchased from a Bodija traditional market, Ibadan. The tubers were identified and evaluated at the Herbarium section of Department of Botany, University of Ibadan. They were fresh and without infection.

\section{Sample Treatments}

The samples were prepared by the method of Eleazu et al., (2016). The washed and air-dried tubers were divided into two portions (500 $\mathrm{g}$ each). The first portion (uncooked) was peeled and oven dried at $40{ }^{\circ} \mathrm{C}$ for $18 \mathrm{~h}$. The second portion $(500 \mathrm{~g})$ of potato was cooked in boiling water $(1000 \mathrm{~mL})$ on a covered stainless steel pot for $20 \mathrm{~min}$ using electric stove. Thereafter, the sample was drained off and permitted to cool at ambient temperature for $2 \mathrm{~h}$. The cooled samples were peeled and oven dried at $40{ }^{\circ} \mathrm{C}$ for $18 \mathrm{~h}$. Thereafter, both samples were milled to particle size using laboratory blender. The milled samples were sieved by 0.2 $\mathrm{mm}$ diameter sniffer and the sieved samples were packed in an air-tight plastic and kept in a refrigerator till use.

\section{Preparation of extracts}

Ten $(10 \mathrm{~g})$ of powdered potato samples was macerated in distilled water $(100 \mathrm{~mL})$ for $4 \mathrm{~h}$ in a sealed container and was shaken regularly. The formed slurry was centrifuged at $3000 \mathrm{rpm}$ for 10 min. The supernatants were used immediately for determinations (Olaiya et al., 2018).

\section{Total phenolic (TPC) and total flavonoid (TFC) determination}

The TPC of the samples was evaluated with the method of Kim et al., (2003) and expressed as gallic acid equivalent (GAE).

The TFC of the samples was evaluated using the method of Park et al., (2008) and expressed as quercetin equivalent (QUE).

Total antioxidant capacity (TAC) determination The TAC (Phosphomolybdum assay) of the samples was assayed using the procedure of Prieto diseases, there is continuous search for foods with biological activities as suitable alternative in confectionary industries. Therefore, the study is aimed to investigate the bioactive composition, antioxidant, antidiabetic and anti-lipid peroxidation properties of cooked and uncooked Irish potatoes.

et al. (1999) and expressed as ascorbic acid equivalent (AAE).

\section{2, 2 diphenyl-1-picrylhydrazyl scavenging activity determination (DPPH)}

The DPPH of the potato samples was evaluated with the method of Gyamfi et al., (1999). The absorbance was measured at $520 \mathrm{~nm}$ and percentage inhibition was evaluated as follows (Eq.1):

Percentage inhibition of DPPH $=\left\{\left(A_{C r l} A_{S p l}\right)\right\}$

$\left.\left(A_{C r l}\right)\right\} \times 100$

Where $A_{\mathrm{Spl}}=$ Absorbance of the sample;

$\mathrm{A}_{\mathrm{Crl}}=$ Absorbance of control

\section{Ascorbic acid determination}

Ascorbic acid content $(\mathrm{mg} / \mathrm{g})$ of the samples was assayed by the method of Rutkowski et al., (2007) and calculated with Eq. 2:

Ascorbic acid $=\left(A_{S} / A_{S t}\right) \times C_{S}$

Where $A_{s}=$ Absorbance of sample;

$\mathrm{A}_{\mathrm{St}}=$ Absorbance of standard;

$\mathrm{C}_{\mathrm{S}}=$ Concentration of standard $(\mathrm{mg} / \mathrm{mL})$

\section{Animal treatment}

Four male Wistar albino rats (120-140) g were obtained from the animal house, Department of Physiology, University of Ibadan. The animals were kept for one week to acclimatize before the experiment. They were fed with standard rats chow and water was given ad libitum. The protocols for the experiment were done according to the National Institute of Health guidelines for the use and care of laboratory animals (NIH Publication No. 80-23) revised in 2011 (NIH 2011).

\section{Preparation of pancreas homogenate}

The pancreas homogenate was prepared using the procedure as described by Akinyemi et al. (2013). Rats were anesthetized and euthanized with sodium pentobarbitone; the pancreas was removed and weighed on ice. The tissue was homogenized immediately in cold normal saline water $(1: 4 \mathrm{w} / \mathrm{v}$ of fresh weight). The pancreas homogenate was centrifuged at $3000 \mathrm{rpm}$ for $10 \mathrm{~min}$. The supernatant was used for the lipid peroxidation assay. 


\section{Inhibition of lipid peroxidation (LPO)}

The LPO by the samples was determined according to the procedure of Ohkawa et al. (1973).

\section{Amylase inhibition assay}

Amylase inhibition capacity of the samples was evaluated with the method of Worthington (1993) and percentage inhibition was calculated as follows (Eq. 3):

Percentage inhibition $=\left\{\left(A_{C r l}-A_{S p l}\right) /\left(A_{C r l}\right)\right\} \times 100(3)$

Where $A_{S p l}=$ Absorbance of the sample;

$\mathrm{A}_{\mathrm{Crl}}=$ Absorbance of control.

\section{Glucosidase inhibition assay}

Glucosidase inhibition capacity of the samples was evaluated with the method of Apostolidis et al.

\section{RESULTS}

The result of bioactive components (ascorbic acid, total flavonoids and total phenolics) and total antioxidant capacity is presented in Table 1 . The cooked potato had higher total phenolics content $(79.89 \mathrm{mg} / 100 \mathrm{~g})$ compared to $(77.09 \mathrm{mg} / 100 \mathrm{~g})$ of uncooked potato but there was no significant difference $(\mathrm{p}<0.05)$ between the two samples. Also, on total antioxidant capacity, the two samples exhibited almost the same activities which were not significantly different $(\mathrm{p}<0.05)$ from each other. The TFC of cooked potato $(62.80$ $\mathrm{mg} / 100 \mathrm{~g}$ ) was significantly higher and different $(\mathrm{p}$ $<0.05)$ from the uncooked potato $(36.70$ $\mathrm{mg} / 100 \mathrm{~g})$. The uncooked potato sample had significantly higher ascorbic acid $(50.65 \mathrm{mg} / \mathrm{g}$ ) content than the cooked samples $(33.54 \mathrm{mg} / \mathrm{g}$ ).

The capacity of the uncooked and cooked potatoes to scavenge DPPH is presented in Figure 1. Both samples were able to scavenge DPPH in a doserelated manner $(0.1-0.4 \mathrm{mg} / \mathrm{mL})$ and their $\mathrm{IC}_{50}$ values were calculated and presented in Table 2 . Cooked potato exhibited significant lower $\mathrm{IC}_{50}$ value $(0.32 \mathrm{mg} / \mathrm{mL})$ than uncooked potato $(0.54$ $\mathrm{mg} / \mathrm{mL})$.

The ability of uncooked and cooked samples to inhibit the lipid peroxidation induced in the pancreas homogenate by ferrous sulphate $\left(\mathrm{FeSO}_{4}\right)$ is showed in Figure 2. Cooked sample was able to reduce the generation of thiobarbituric acid reactive substances (TBARS) than uncooked sample. The reductions were not significant ( $\mathrm{p}<$ $0.05)$ when compared cooked and uncooked samples.

The result of $\alpha$-glucosidase and $\alpha$-amylase enzymes inhibition by the samples is presented in
(2007) and percentage inhibition was calculated with Eq. 4:

Percentage inhibition $=\left\{\left(A_{C r l}-A_{S p l}\right) /\left(A_{C r l}\right)\right\} \times 100$ (4)

Where $\mathrm{A}_{\mathrm{spl}}=$ Absorbance of the sample;

$\mathrm{A}_{\mathrm{Crl}}=$ Absorbance of control.

\section{Statistical analysis}

The result is presented as the mean \pm SD of three readings. The significance was established using least significant difference (LSD) post hoc treatment of analysis of variance (ANOVA) at $p<$ 0.05 . The Pearson correlation test was done to evaluate the correlation among antioxidant activities, total phenolics, total flavonoids and enzyme inhibitions.

Figure 3. Like DPPH, both samples were able to inhibit the activities of the carbohydrate metabolizing enzymes in a concentration-related manner. The results of $\mathrm{IC}_{50}$ values (Table 2) revealed that the cooked potato had significantly lower $(\mathrm{p}<0.05) \mathrm{IC}_{50}$ than the uncooked potato for the enzymes.

Table 1: TPC, TFC, TAC and AsA of cooked and uncooked potatoes

\begin{tabular}{|l|l|l|}
\hline & UP & CP \\
\hline $\begin{array}{l}\text { Total phenolics (mg } \\
\text { GAE/ 100g) }\end{array}$ & $77.09 \pm 2.30^{\mathrm{a}}$ & $79.89 \pm 0.90^{\mathrm{a}}$ \\
\hline $\begin{array}{l}\text { Total flavonoid }(\mathrm{mg} \\
\text { QUE/ 100g) }\end{array}$ & $36.70 \pm 1.70^{\mathrm{b}}$ & $62.80 \pm 1.20^{\mathrm{a}}$ \\
\hline $\begin{array}{l}\text { Total antioxidant capacity } \\
\text { (mg AAE/ 100g) }\end{array}$ & $52.56 \pm 2.11^{\mathrm{a}}$ & $52.50 \pm 2.10^{\mathrm{a}}$ \\
\hline Ascorbic acid $(\mathrm{mg} / \mathrm{g})$ & $50.65 \pm 2.36^{\mathrm{a}}$ & $33.5 \pm 1.46^{\mathrm{b}}$ \\
\hline
\end{tabular}

Values represent Mean \pm SD. Values with same letter across the row are not different significantly $(\mathrm{p}<0.05)$. $\mathrm{UP}=$ Uncooked potato, $\mathrm{CP}=$ Cooked potato

Table 2: $\mathrm{IC}_{50}(\mathrm{mg} / \mathrm{mL})$ of DPPH, $\alpha$-amylase and $\alpha$ glucosidase of cooked and uncooked potatoes

\begin{tabular}{|l|l|l|}
\hline & UP & CP \\
\hline DPPH & $0.54 \pm 0.05^{\mathrm{a}}$ & $0.32 \pm 0.03^{\mathrm{b}}$ \\
\hline$\alpha$-amylase & $0.64 \pm 0.06^{\mathrm{a}}$ & $0.52 \pm 0.05^{\mathrm{b}}$ \\
\hline$\alpha$-glucosidase & $0.53 \pm 0.04^{\mathrm{a}}$ & $0.38 \pm 0.04^{\mathrm{b}}$ \\
\hline
\end{tabular}

Values represent Mean \pm SD. Values with same letter across the row are not different significantly $(\mathrm{p}<0.05)$. $\mathrm{UP}=$ Uncooked potato, $\mathrm{CP}=$ Cooked potato

The correlation analysis (Table 3) revealed a positive relationship among polyphenol, antioxidant and enzyme inhibition assays. The relationships were significant $(\mathrm{p}<0.05)$ between TPC and TAC; TPC and DPPH; TPC and $\alpha-$ glucosidase; DPPH and $\alpha$-amylase; $\alpha$-amylase and $\alpha$-glucosidase. 
DPPH

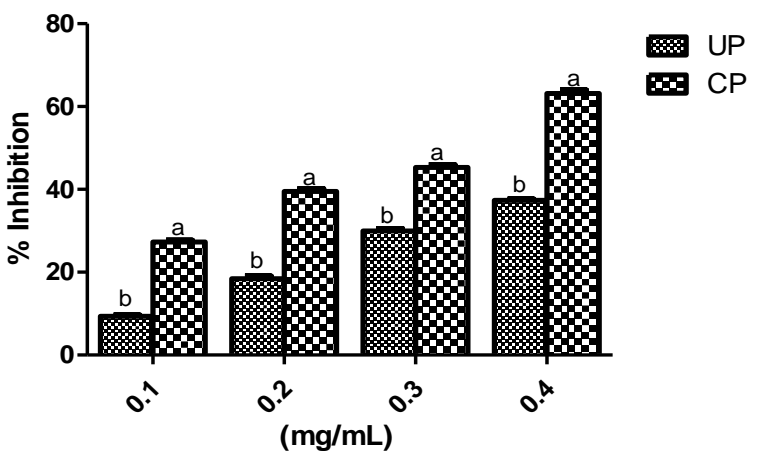

Figure 1: DPPH scavenging effect of cooked and uncooked potatoes. Values with similar letter are not different significantly $(\mathrm{p}<0.05) . \mathrm{CP}=$ Cooked potato, $\mathrm{UP}=$ Uncooked potato

\section{Amylase}

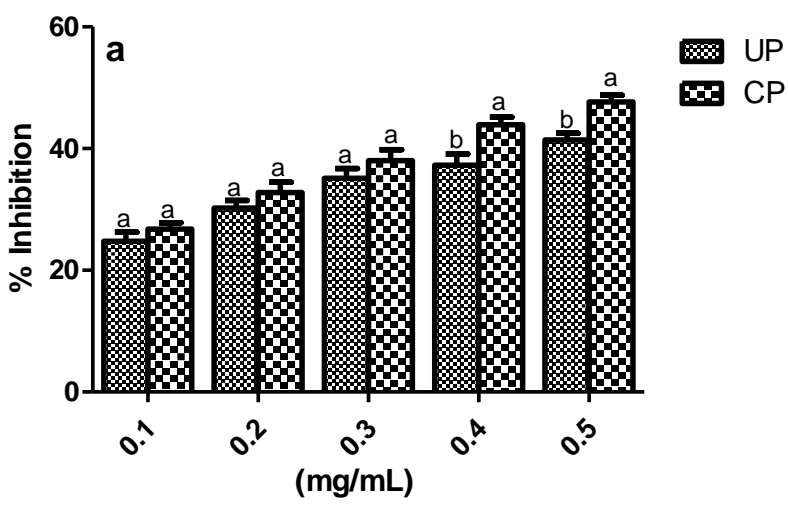

LPO

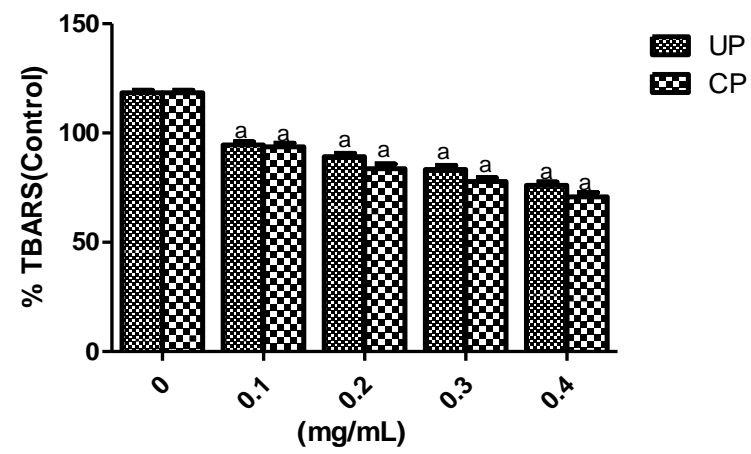

Figure 2: Lipid peroxidation inhibition of cooked and uncooked potatoes. Values with similar letter are not different significantly $(\mathrm{p}<0.05)$. $\mathrm{CP}=$ Cooked potato, $\mathrm{UP}=$ Uncooked potato

\section{Glucosidase}

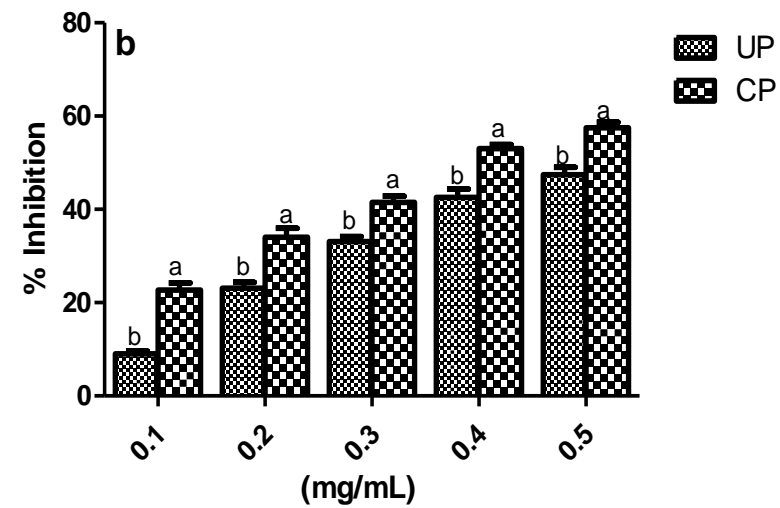

Figure 3: $\alpha$-amylase and $\alpha$-glucosidase inhibitions of cooked and uncooked potatoes. Values with similar letter are not different significantly $(\mathrm{p}<0.05) . \mathrm{CP}=$ Cooked potato, $\mathrm{UP}=$ Uncooked potato

Table 3: Correlations among TPC, TFC, TAC, DPPH, $\alpha$ - amylase and $\alpha$-glucosidase

\begin{tabular}{|l|l|l|l|l|l|l|}
\hline & TPC & TFC & TAC & DPPH & $\alpha$-amylase & $\alpha$-glucosidase \\
\hline TPC & 1 & & & & & \\
\hline TFC & 0.54 & 1 & & & & \\
\hline TAC & $0.88^{*}$ & 0.35 & 1 & & & \\
\hline DPPH & $0.90^{*}$ & 0.78 & 0.66 & 1 & & \\
\hline$\alpha$-amylase & 0.81 & 0.31 & 0.58 & $0.81^{*}$ & 1 & \\
\hline$\alpha$-glucosidase & $0.84^{*}$ & 0.57 & 0.63 & $0.92^{*}$ & $0.95^{*}$ & 1 \\
\hline
\end{tabular}

* Correlation is significant at the $(\mathrm{p}<0.05) . \mathrm{TPC}=$ total phenolics content, $\mathrm{TFC}=$ total flavonoids content, $\mathrm{TAC}=$ total antioxidant capacity, DPPH = 1,1-diphenyl-2-picrylhydrazyl (DPPH) radical scavenging activity

\section{DISCUSSION}

Recently, people's awareness about the health benefits of foods has made them an essential component in the avoidance and management of many chronic diseases. Also, food processing such as cooking has been reported to influence polyphenols, antioxidant and health functionality of foods (Karigidi et al., 2019; Garretson et al., 2018). In this study, bioactive, antioxidant and antidiabetic properties of cooked and uncooked Irish potatoes were investigated. Bioactive compounds; ascorbic acid, flavonoids and phenolics have been reported to exhibit diverse antioxidant activities. Phenolics and flavonoids are examples of group of phytochemical termed 
polyphenols. They are called polyphenols because of numerous phenol rings in their chemical structures. Due to their vast antioxidant potential, they are utilized in the prevention, management and treatment of many diseases.

The TPC and TFC of the potato samples in this study ranked very high with other tuber crops; Cocoyam-Colocasia esculenta L. schott and Sweet potato-Ipomoea batatas L. (Karigidi et al., 2019, Musilova et al., 2020).

Antioxidant ability of the potato sample was evaluated using the total antioxidant capacity and DPPH assays. DPPH assay measures the hydrogen donating ability of a reductant. The donation of hydrogen in this assay leads to loss of violet colour of DPPH. The capacity of the cooked and uncooked Irish potatoes to scavenge DPPH in this study ranked very well when compared with purple fleshed potatoes and cocoyam (Karigidi et al., 2019, Tian et al., 2016). Also, Pearson correlation analysis revealed strong positive relationship between the polyphenol contents and the scavenging activity.

Lipid peroxidation has been implicated in DM and many chronic diseases especially hypertension (Alharby et al., 2019). In this study, lipid peroxidation was stimulated by the pro-oxidant ability of $\mathrm{FeSO}_{4}$; the capacity of the cooked and uncooked potatoes to inhibit the induced lipid

\section{CONCLUSION}

It can be concluded that Irish potato (Solanum tuberosum L.) possessed bioactive compounds, antioxidant capacity, abilities to inhibit $\alpha$ glucosidase and $\alpha$-amylase enzymes and inducedlipid peroxidation in pancreas homogenate.

\section{Conflict of interest}

The authors declare there is no conflict of interest. peroxidation was evaluated by the thiobarbituric acid reactive species (TBARS) formed.

The enhanced ability of cooked Irish potato to inhibit the formation of TBARS might also be linked to enhanced flavonoid content in the cooked sample. Flavonoid has been reported to ameliorate the enhanced loss of function of pancreatic cells by free radical, therefore mitigate the onset of DM (Karigidi and Olaiya 2019, Song et al., 2005). The study corroborated the work of other researchers where thermal treatment increased the inhibitory power of Solanum melongena $\mathrm{L}$ via increase in polyphenolic compound (Lo- Scalzo et al., 2010).

Antidiabetic property of the cooked and uncooked Irish potatoes was assayed by their abilities to inhibit $\alpha$-glucosidase and $\alpha$-amylase enzymes. These enzymes are known to catalyze the breaking of carbohydrate molecules into smaller absorbable unit thereby causing elevation of blood sugar after a meal. Many studies have confirmed their relevance in DM treatment (Shim et al., 2003, Rasouli et al., 2017, Kruczek et al., 2020).

Both samples i.e. the cooked and uncooked potatoes were able to inhibit the enzymes but the enhanced inhibition by the cooked sample might be linked to increase flavonoid content. This study corroborated the results of previous studies which confirmed flavonoid as inhibitor of $\alpha$-glucosidase and $\alpha$-amylase enzymes (Tadera et al., 2006; Li et al., 2018; Zhu et al., 2020).

However, the abilities to inhibit the carbohydrate metabolizing enzymes and lipid peroxidation were enhanced upon cooking.

From the data obtained in this study, the use of cooked Irish potato (Solanum tuberosum) should be encouraged especially in confectionary industries.

\section{REFERENCES}

1. Akinyemi, A.J., Ademiluyi, A.O., \& Oboh, G. (2013). Aqueous Extracts of Two Varieties of Ginger (Zingiber officinale) Inhibit Angiotensin I-Converting Enzyme, Iron(II), and Sodium NitroprussideInduced Lipid Peroxidation in the Rat Heart InVitro. Journal of Medicinal Food, 16, 641-646.

2. Alharby, H., Abdelati, T., Rizk, M., Youssef, E., Moghazy, K., Gaber, N., \& Yafei S. (2019). Association of lipid peroxidation and interleukin-6 with carotid atherosclerosis in type 2 diabetes. Cardiovascular Endocrinology and Metabolism, 8(3), 73-76.

3. Apostolidis, E., Kwon, Y.I., \& Shetty, K. (2007). Inhibitory potential of herb, fruit, and fungal enriched cheese against key enzymes linked to type-2 diabetes and hypertension. Innovative Food Science and Emerging Technologies, 8, 46-54. 
4. Eke-ejiofor, J. (2015) Functional properties of starches, physico-chemical and rheological properties of glucose syrup made from cassava and different potato varieties. International Journal of Recent Scientific Research, 6(6) 4400-4406

5. Eleazu, C.O., Eleazu, K.C., \& Iroaganachi, M. (2016). In vitro starch digestibility, $\alpha$-amylase and $\alpha$ glucosidase inhibitory capacities of raw and processed forms of three varieties of Livingstone potato (Plectranthus esculentus). Innovative Food Science and Emerging Technologies, 37, 37-43

6. Garretson, L., Tyl, C., \& Marti, A. (2018). Effect of Processing on Antioxidant Activity, Total Phenols, and Total Flavonoids of Pigmented Heirloom Beans Journal of Food Quality https:// doi.org $/ 10.1155 / 2018 / 7836745$

7. Griesmacher, A., Kindhauser, M., Andert, S.E., Schreiner, W., Toma, C., Knoebi, P. et al., (1995). Enhanced serum level of thiobarbituric-acid reactive substances in diabetes mellitus. The American Journal of Medicine, 98(5), 469-475

8. Gyamfi, M., Yonamine, M., \& Aniya, Y. (1999). Free radical scavenging action of medicinal herbs from Ghana: Thonningia sanguine on experimentally induced liver injuries. General Pharmacology, 32(6), 661-667.

9. Heidemann, C., Schulze, M.B., Franco, O.H., van Dam, R.M., Mantzoros, C.S., \& Hu, F.B. (2008). Dietary patterns and risk of mortality from cardiovascular disease, cancer, and all causes in a prospective cohort of women. Circulation, 118, 230-237.

10. Ikanone, C.E.O., \& Oyekan, O.O. (2014). Effect of Boiling and Frying on the Total Carbohydrate, Vitamin C and Mineral Contents of Irish (Solanun tuberosum) and Sweet (Ipomea batatas) Potato Tubers. Nigerian Food Journal, 32(2) 33-39.

11. International Diabetes Federation (2019). The IDF Diabetes Atlas, Ninth Edition; Belguim

12. Kabira, J.N., Imungi, J.K. (1991). Possibility of incorporating potato flour into the traditional Kenya foods. Afr Study Monographs, 12 (4), 211-217.

13. Karigidi, K.O., Adetuyi, F.O., Akintimehin, E.S., Dada, I.O., \& Olugotun, A.F. (2019). Effect of cooking methods on polyphenol, antioxidant and inhibition of key enzymes linked to carbohydrate metabolism of cocoyam (Colocasia esculenta L. schott). Annal. Food Science and Technology, 20(3), 543-552.

14. Karigidi, K.O., \& Olaiya, C.O. (2019). In vitro Antidiabetic, Antioxidant and Anti-lipid peroxidative Activities of Corn Steep Liquor Extracts of Curculigo pilosa and its Solvent Fractions. Journal of Herbs, Spices and Medicinal Plants, 25(4), 377-388.

15. Kim, D.O., Jeong, S.W., \& Lee, C.Y. (2003). Antioxidant capacity of phenolic phytochemicals from various cultivars of plums. Food Chemistry, 81, 321-326.

16. Kruczek, A., Ochmian I., Krupa-malkiewicz., \& Lachowicz S. (2020). Comparison of morphological, antidiabetic and antioxidant properties of Goji fruits. Acta Universitatis Cibiniensis Series E: Food Technology 24(1), 1-8.

17. Li, K. Yao, F. Xue, Q. et al., (2018). Inhibitory effects against $\alpha$-glucosidase and $\alpha$-amylase of the flavonoids-rich extract from Scutellaria baicalensis shoots and interpretation of structure-activity relationship of its eight flavonoids by a refined assign-score method. Chemistry Central Journal, 12, 82.

18. Lo-Scalzo, R,, Fibiani, M., Mennella, G., Rotino, G., Dal, S.M., Culici, M., \& Braga, P. (2010). Thermal treatment of eggplant (Solanum melongena L.) increases the antioxidant content and the inhibitory effect on human neutrophil burst. Journal of Agriculture and Food Chemistry, 58(6), 33713379.

19. Musilova, J., Lidikova, J., Vollmannova, A., Frankova, H., Urminska, D., Bojnanska, T., \& Toth, T. (2020). Influence of Heat treatments on the content of bioactive substances and antioxidant properties of sweet potato (Ipomoea batatas L.) tubers. Journal of Food quality https://doi.org/10.1155/ 2020/8856260

20. National Research Council (US) (2011). Committee for the Update of the Guide for the Care and Use of Laboratory Animals. Guide for the Care and Use of Laboratory Animals. $8^{\text {th }}$ edition. Washington DC: National Academies Press (US).

21. Ohkawa, H., Ohishi, N., \& Yagi, K. (1979). Assay for lipid peroxides in animal tissues by thiobarbituric acid reaction. Analytical Biochemistry, 95, 351-358.

22. Olaiya, C. O., Soetan, K.O., \& Karigidi K.O. (2018). Evaluation of In Vitro Antioxidant Capacities of Six Accessions of Winged Beans (Psophocarpus tetragonolobus). EC Nutrition 13(8), 589-595.

23. Park, Y-S., Jung, S-T., Kang, S-G., Heo, B.K., Arancibia-Avila, P., Toledo, F. et al., (2008). Antioxidants and proteins in ethylene-treated kiwifruits. Food Chemistry, 107, 640-648. 
24. Prieto, P., Pineda, M., \& Aguilar, M. (1999). Spectrophotometric quantitation of antioxidant capacity through the formation of a phosphomolybdenum complex: specific application to the determination of vitamin E. Analytical Biochemistry, 26(9), 337-341.

25. Rasouli, H., Hosseini-Ghazvini, S., Adibia, H., \& Khodarahmi, R. (2017). Differential $\alpha$-amylase/ $\alpha$ glucosidase inhibitory activities of plant-derived phenolic compounds: a virtual screening perspective for the treatment of obesity and diabetes. Food Function, 8, 1942-1954.

26. Rutkowski M, \& Grzegorczyk, K. (2007) Modifications of spectrophotometric methods for antioxidative vitamins determination convenient in analytic practice. Acta Scientarum. Polonorum., Technologia Aliment, 6(3), 17-28.

27. Samsher, V., Singh, B.R., Chandra, S. et al., (2020). Development of potato flour based cookies and quality evaluation. The Pharma Innovation Journal, 9(9), 527-532.

28. Shim, Y., Doo, H, Ahn, S., Kim, Y.S., Seong, J.K., Park, I.S., \& Min, B. (2003). Inhibitory Effect of Aqueous Extract from the Gall of Rhuz chinesis on Alpha-glucosidase Activities and Postprandial Blood Glucose. Journal of Ethnopharmacology, 85, 283-287.

29. Song, Y., Manson, J.E., Buring, J.E., Sesso, H.D., \& Liu, S. (2005). Association of Dietary Flavonoids with Risk of Type 2 Diabetes, and Markers of Insulin Resistance and Systemic Inflammation in Women: A Prospective Study and Cross Sectional Analysis. Journal of the American College of Nutrition, 24(5), 376-384.

30. Tadera, K., Minami, Y., Takamatsu, K., \& Matsuoka, T. (2006). Inhibition of alpha-glucosidase and alpha amylase by flavonoids. Journal of Nutritional Science and Vitaminology, 52, 149-153.

31. Tian, J., Chen, J., Lv, F., Chen, S., Chen, J., Liu, D., \& Ye, X. (2016). Domestic cooking methods affect the phytochemical composition and antioxidant activity of purple-fleshed potatoes Food Chemistry, 197, 1264-1270.

32. Wailare, A.M, \& Madu, A.I. (2019). Yield variability of Irish potato (Solanum tuberosum L.) as affected by cultivars and sowing date in the Sudan Savanna Zone of Nigeria. Journal of Dryland Agriculture, $5(4), 33-41$.

33. Worthington, V., (1993). Alpha amylase. In: Worthington Enzyme Manual. Freehold: Worthington Biochemical Corp: $36-41$.

34. Wronkowska, M., Honke, J., Zieliński, H., \& Wiczkowski, W. (2020). Biscuits from Fermented Roasted Buckwheat Flour - Phenolics Profile and Bioaccessible Angiotensin Converting Enzyme Inhibitory Activity. Acta Universitatis Cibiniensis Series E: Food Technology 24(2), 205-214

35. Zhu. J., Chen, C., Zhang, B., \& Huang, Q. (2020). The inhibitory effects of flavonoids on $\alpha$-amylase and $\alpha$-glucosidase. Critical Reviews in Food Science and Nutrition, 60(4) 695-708. 